\title{
Pembuatan Program Aplikasi Pembelajaran Matematika Dasar Untuk Kelas 3 \& 4 Pada SD Dharma Putra
}

\author{
Aprilia Rachmawati \\ Program Studi Sistem Informasi \\ STMIK Dharma Putra \\ shigatsu_9489@yahoo.com
}

\author{
Yakub \\ Fakultas Sains dan Teknologi \\ Universitas Buddhi Dharma \\ y44kub@yahoo.com
}

\author{
Dram Renaldi \\ Fakultas Sains dan Teknologi \\ Universitas Buddhi Dharma \\ dramrenaldi@gmail.com
}

\begin{abstract}
Abstrak- Penelitian ini dilatar belakangi Pembelajaran Matematika di Sekolah Dasar, pembelajaran yang menggunakan metode dan media yang tepat dapat membangkitkan minat dan motivasi siswa untuk belajar. Dari latar belakang tersebut penulis menerapkan sebuah program aplikasi Pembelajaran Matematika Dasar untuk Kelas 3 dan 4. Penelitian ini dilaksanakan di SD Dharma Putra Tangerang. Pembuatan Program Aplikasi itu menggunakan program pendukung Visual Basic 6.0 dan untuk database menggunakan Ms Access 2007. Program tersebut memuat rumus-rumus matematika. Program tersebut juga menyediakan latihan soal untuk kelas 3 dan 4 yang dibuat oleh guru sebagai admin. Guru dapat mengimput nilai dari soal-soal yang dikerjakan siswa. Penelitian tersebut menghasilkan program matematika yang lebih mudah dipahami dan juga menampilkan user interface yang menarik. Serta membantu memudahkan guru untuk menyampaikan materi rumus dasar matematika. Untuk kedepannya diperlukan pengembangan yang lebih dari program tersebut, dengan menambahkan materi-materi pelajaran matematika yang kurang, agar program tersebut dapat sesuai dengan standar kompetensi jenjang pendidikan yang ada.
\end{abstract}

Kata Kunci-Pembelajaran, Matematika, Program

\section{Pendahuluan}

Anak Sekolah Dasar diajarkan dasar dari ilmu pasti sejak dini yang kemudian akan mereka pelajari lebih dalam lagi pada tingkat ajaran berikutnya. Sehingga pada jenjang pembelajaran inilah, anak diberikan ilmu pengetahuan dasar dengan pendekatan yang lebih halus dan mudah dimengerti, sehingga mereka dapat menyerap informasi yang diberikan dengan baik oleh guru. Strategi pembelajaran yang diberikan ada baiknya yaitu strategi pembelajaran dengan media pembelajaran yang lebih menarik perhatian dan minat mereka, sehingga anak tidak merasa bosan dan menganggap pembelajaran yang diberikan sulit dan menekan.

Yayasan Pendidikan Dharma Putra mendirikan Sekolah Dasar Dharma Putra pada tanggal 19 April 1984. Total murid yang aktif dari kelas 1 sampai 6 saat ini berjumlah 557 siswa. Dan memiliki total tenaga pengajar 22 orang. Terdapat 74 siswa di kelas 3 dan 73 siswa di kelas 4. Yang menerima kurang lebihnya pelajaran matematika 7 jam selama seminggu.
Kenyataannya, banyak anak-anak di Sekolah Dasar yang kesulitan dalam pelajaran matematika dasar khususnya berhitung. Begitu pula yang terjadi pada anak-anak di SD Dharma Putra khususnya kelas 3 dan 4. Kesulitan tersebut bisa disebabkan oleh beberapa hal, misalnya metode yang diajarkan kurang dapat dimengerti oleh murid, materi yang berupa angka-angka yang dapat menguras tenaga dan pemikiran anak selama pembelajaran, media pembelajaran yang kurang, lingkungan yang tidak memungkinkan, dan lain-lain. Dengan media belajar yang lebih menarik sudah pasti akan menarik minat anak untuk belajar.

Aplikasi ini diharapkan dapat membantu anak-anak untuk cepat menguasai rumus-rumus matematika dasar, dan mengimplementasikan dalam kehidupan sehari-hari. Aplikasi ini memuat rumus-rumus matematika dasar dan membantu penilaian guru dalam pembelajaran matematika ini. Pembuatan aplikasi ini ditujukan untuk anak-anak kelas 3 dan 4 Sekolah Dasar.

\section{TinjauAn PUSTAKA}

\section{A. Sistem}

Sistem didefinisikan sebagai suatu kesatuan yang terdiri dari dua atau lebih komponen atau subsistem yang berinteraksi untuk mencapai suatu tujuan [1]. Menurut McLeod, Jr. yang diterjemahkan oleh Latip Diat Prasojo menyatakan bahwa sistem adalah sekelompok elemen yang terintegrasi dengan maksud yang sama untuk mencapai suatu tujuan [4]. Dapat disimpulkan bahwa definisi sistem adalah elemen-elemen yang terintegrasi dan saling berhubungan untuk mencapai suatu tujuan yang diinginkan.

\section{B. Informasi}

Informasi [1] adalah hasil dari pengolahan data dalam suatu bentuk yang lebih berguna dan lebih berarti bagi penerimanya yang menggambarkan suatu kejadian-kejadian (event) yang nyata (fact) yang digunakan untuk pengambilan keputusan.

Menurut McLeod, Jr. yang diterjemahkan oleh Latip Diat Prasojo informasi adalah data yang diolah menjadi bentuk yang 
lebih berguna dan lebih berarti bagi yang menerimanya. Informasi juga disebut data yang diproses atau memiliki arti [4].

Kesimpulan dari informasi adalah hasil dari pengolahan data menjadi bentuk yang lebih berguna bagi yang menerimanya dan menggambarkan suatu kejadian-kejadian nyata yang dapat digunakan sebagai alat bantu untuk pengambilan suatu keputusan.

\section{Sistem Informasi}

Sistem informasi adalah suatu sistem di dalam suatu organisasi yang merupakan kombinasi dari orang-orang, fasilitas, teknologi, media, prosedur-prosedur, dan pengendalian yang ditujukan untuk mendapatkan jalur komunikasi penting, memproses tipe transaksi rutin tertentu, memberi sinyal kepada manajemen dan yang lainnya terhadap kejadian-kejadian internal dan eksternal yang penting, dan menyediakan suatu dasar informasi untuk pengambilan keputusan yang cerdik [1].

Sedangkan menurut Henry Lucas yang diterjemahkan oleh Jogiyanto H.M, menyatakan bahwa, Sistem Informasi adalah suatu kegiatan dari prosedur-prosedur yang diorganisasikan, bilamana dieksekusi akan menyediakan informasi untuk mendukung pengambilan keputusan dan pengendalian di dalam organisasi [1].

Dapat disimpulkan bahwa sistem informasi menyediakan informasi untuk membantu pengambilan keputusan manajemen, operasi perusahaan dari hari ke hari dan informasi yang layak untuk pihak luar perusahaan.

\section{Pembelajaran}

Belajar merupakan suatu kekuatan atau sumber daya yang tumbuh dari dalam diri seseorang (individu). Belajar adalah proses perubahan perilaku, akibat interaksi individu dengan lingkungan. Jadi perubahan perilaku adalah hasil belajar. Artinya, seseorang dikatakan telah belajar, jika ia dapat melakukan sesuatu yang tidak dapat dilakukan sebelumnya. Perilaku itu meliputi aspek pengetahuan (kognitif), sikap (afektif), dan keterampilan (psikomotor). Hasil belajar pada aspek pengetahuan adalah dari tidak tahu menjadi tahu, pada aspek sikap dari tidak mau menjadi mau, dan pada aspek keterampilan dari tidak mampu menjadi mampu [5].

Pembelajaran adalah proses pencarian ilmu pengetahuan secara aktif atau proses perumusan ilmu, bukan proses mengungkap ilmu semata. Dalam proses pembelajaran pada diri peserta didik harus ditanamkan rasa percaya diri dan rasa mampu (bisa melakukan sesuatu), berguna (bisa menyumbangkan sesuatu), memiliki (menjadi bagian dari masyarakat dan memiliki hubungan dengan orang dewasa yang saling menyayangi), dan berdaya (memiliki kendali atas masa depannya sendiri) [5].

\section{E. Matematika}

Istilah matematika berasal dari bahasa Yunani "mathein" atau "manthenein" artinya "mempelajari", namun diduga kata itu ada hubungannya dengan kata Sansekerta "medha" atau "widya" yang artinya "kepandaian", "ketahuan", atau "intelegensi" [2].

Matematika adalah salah satu pengetahuan tertua, terbentuk dari penelitian bilangan dan ruang. Matematika adalah suatu disiplin ilmu yang berdiri sendiri dan tidak merupakan cabang dari ilmu pengetahuan alam. Matematika merupakan alat dan bahasa dasar banyak ilmu.

Menurut beberapa para ahli dapat dikatakan bahwa matematika merupakan suatu ilmu yang berhubungan dengan penelaahan bentuk-bentuk atau struktur-struktur yang abstrak dan hubungan di antara hal-hal tersebut. Untuk dapat memahami struktur serta hubungan-hubungannya diperlukan penguasaan tentang konsep-konsep yang terdapat dalam matematika.

\section{F. Pembelajaran Matematika Dasar}

Dalam belajar matematika diperlukan pemahaman dan penguasaan materi terutama dalam membaca simbol, tabel dan diagram yang sering digunakan dalam matematika serta struktur matematika yang kompleks, dari yang konkret sampai yang abstrak, apalagi jika yang diberikan adalah soal dalam bentuk cerita yang memerlukan kemampuan penerjemahan soal kedalam kalimat matematika dengan memperhatikan maksud dari pertanyaan soal tersebut.

Manfaat belajar matematika yang menonjol adalah dari matematika dapat membentuk pola pikir orang yang mempelajarinya menjadi pola pikir matematis, logis, kritis, dengan penuh kecermatan. Namun sayangnya, pengembangan sistem atau model matematika itu tidak selalu sejalan dengan perkembangan berpikir anak terutama pada anak-anak usia SD. Apa yang dianggap logis dan jelas oleh para ahli dan apa yang dapat diterima oleh orang yang berhasil mempelajarinya, merupakan hal yang tidak masuk akal dan membingungkan bagi anak-anak [3].

\section{G. Computer Assisted Instruction (Perangkat Ajar Berbasiskan Komputer)}

Computer Assited Instruction adalah suatu cara belajar yang efektif. Orang harus belajar secara berkesinambungan dengan mengerjakan pertanyaan yang disediakan, memilih topik, bertanya dan sebagainya. Konsep ini diharapkan dapat mengubah cara belajar yang pasif menjadi aktif [1]. Computer Assited Instruction adalah alat bantu pengajaran berbasiskan komputer dengan program yang interaktif. Dengan menggunakan perangkat ini, proses belajar menjadi lebih aktif. Perangkat ini dapat digunakan sebagai alat utama atau alat bantu pengajaran.

Agar dapat menghasilkan cara belajar yang aktif bagi pemakainya, suatu perangkat ajar yang baik seharusnya user friendly, mudah dimengerti, memerlukan waktu belajar yang minimum dan bisa digunakan dari berbagai komputer pribadi. 


\section{ANALISA DAN PERANCANGAN}

\section{A. Analisa Sistem yang Berjalan}

Sistem Informasi Pembelajaran Matematika di kelas 3 dan 4 pada SD Dharma Putra digambarkan pada dokumen flowchart, dapat dilihat pada Gambar 1.

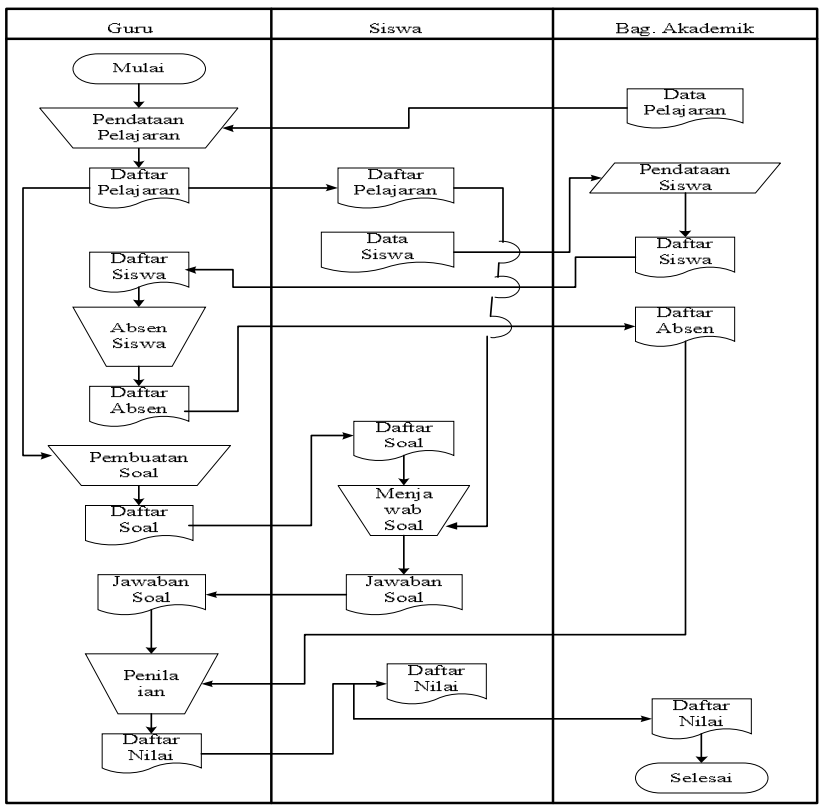

Gambar 1. Flowchart Sistem Informasi yang Berjalan

Dari gambar tersebut dijelaskan sebagai berikut:

1) Guru membuat pendataan pelajaran dengan data pelajaran yang diperoleh dari Bag. Akademik dan menghasilkan daftar pelajaran untuk proses belajar siswa.

2) Bagian Akademik melakukan pendataan siswa yang memperoleh data siswa dari siswa, dan menghasilkan daftar siswa yang akan diterima guru.

3) Dari daftar siswa yang diterima, guru lalu membuat absen siswa dan menghasilkan daftar absen yang akan diterima Bagian Akademik.

4) Guru membuat soal dari daftar pelajaran yang kemudian menghasilkan daftar soal yang akan diterima siswa.

5) Dari daftar soal yang diterima, siswa menjawab soal dan menghasilkan jawaban soal yang akan diterima guru.

6) Dari jawaban soal, guru melakukan penilaian dan menghasilkan daftar nilai yang nantinya akan diberikan kepada siswa dan Bag. Akademik.

\section{B. Rancangan Proses}

Berikut ini merupakan rancangan proses Sistem Informasi Pembelajaran Matematika Dasar untuk Kelas 3 dan 4 pada SD Dharma Putra dengan menggunakan Data Flow Diagram (DFD), meliputi :

\section{1) Konteks Diagram}

Rancangan proses Sistem Informasi Pembelajaran Matematika Dasar untuk kelas 3 dan 4 pada SD Dharma Putra dimulai dengan pembuatan Konteks Diagram yang dapat dilihat pada Gambar 2.

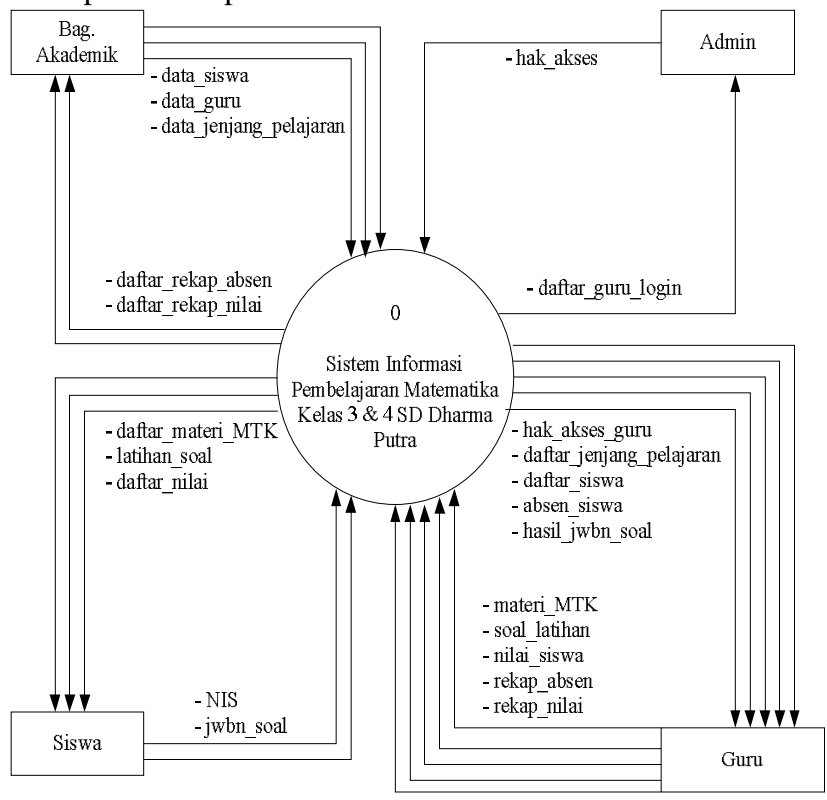

Gambar 2. Konteks Diagram Sistem Informasi Pembelajaran Matematika Dasar untuk Kelas 3 dan 4 pada SD Dharma Putra

Berikut adalah penjelasannya:

a) Bag. Akademik memberikan data siswa, dari data tersebut menghasilkan daftar siswa, kemudian diserahkan kepada guru.

b) Bag. Akademik memberikan data guru, dari data tersebut menghasilkan daftar guru login, yang digunakan sebagai admin.

c) Admin memberikan hak akses guru kepada guru.

d) Bag. Akademik memberikan data jenjang pelajaran, dan menghasilkan daftar jenjang pelajaran, yang diserahkan kepada guru.

e) Siswa memberikan NIS, dengan NIS tersebut menghasilkan absen siswa, yang diserahkan kepada guru.

f) Guru memberikan materi MTK, dan materi tersebut diterima oleh siswa.

g) Guru memberikan soal latihan, dan menghasilkan latihan soal yang diserahkan kepada siswa.

h) Siswa memberikan jawaban soal, dan menghasilkan hasil jawaban soal yang diserahkan kepada guru.

i) Guru memberikan nilai siswa, dari nilai tersebut menghasilkan daftar nilai yang diserahkan kepada siswa.

j) Guru memberikan rekap absen, dari rekap absen tersebut menghasilkan daftar rekap absen yang diserahkan kepada Bag. Akademik. 
k) Guru membuat rekap nilai, dari rekap nilai tersebut menghasilkan daftar rekap nilai yang diserahkan kepada Bag. Akademik.

\section{2) Diagram Overview (Level 0)}

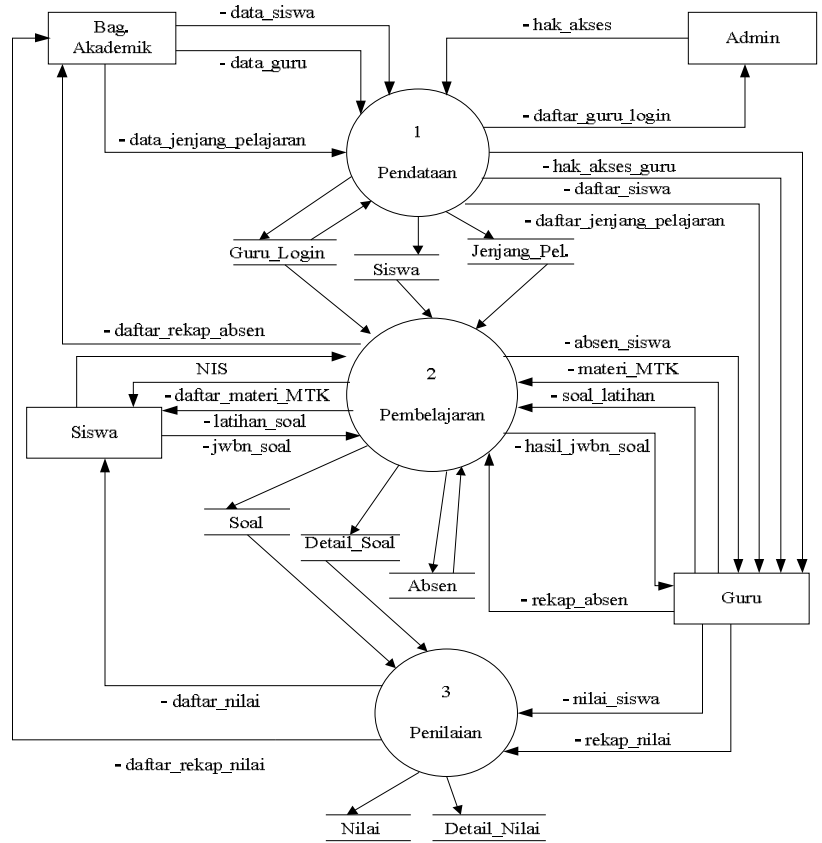

Gambar 3. Diagram Overview (Level 0) Sistem Informasi Pembelajaran matematika Dasar untuk Kelas 3 dan 4

Pada gambar tersebut dijelaskan sebagai berikut:

a) Proses pendataan, proses ini dimulai dari input data siswa dan menghasilkan daftar siswa yang disimpan pada file Siswa. Lalu input data guru dan menghasilkan daftar guru login yang disimpan pada file Guru _Login. Lalu input data jenjang pelajaran dan menghasilkan daftar jenjang pelajaran yang disimpan pada file Jenjang_Pel. Proses selanjutnya yaitu pemberian hak akses guru kepada guru.

b) Proses pembelajaran, proses ini dimulai dengan input NIS dari siswa dan menghasilkan absen siswa yang disimpan pada file Absen. Lalu pemberian materi MTK oleh guru ke siswa. Lalu input soal latihan dan menghasilkan latihan soal yang disimpan pada file Soal dan Detail_Soal. Proses berikutnya siswa memberikan jawaban soal dan menghasilkan hasil jawaban soal yang diterima guru. Lalu guru membuat rekap absen yang akan diserahkan kepada Bag. Akademik sebagai daftar rekap absen.

c) Proses penilaian, proses ini dimulai dari input nilai siswa dan menghasilkan daftar nilai yang disimpan pada file Nilai dan Detail_Nilai. dari file tersebut guru membuat rekap nilai dan menghasilkan daftar rekap nilai yang akan diserahkan kepada Bag. Akademik.

3) Diagram Rinci (Level 1) Proses 1

Diagram Rinci (Level 1) Proses 1 digunakan untuk menguraikan proses yang ada pada diagram Overview, berikut rincian proses pandataan dapat dilihat pada Gambar 4. Pada Proses pendataan dirinci menjadi 3 subproses, yaitu proses pendataan siswa, pendataan guru, dan pendataan hak akses.

Berikut penjelasannya:

a) Proses Pendataan Siswa, proses ini menginput data siswa menjadi daftar siswa yang disimpan dalam file Siswa.

b) Proses Pendataan Jenjang Pelajaran, proses ini mengimput data jenjang pelajaran menjadi daftar jenjang pelajaran yang disimpan pada file Jenjang_Pel.

c) Proses Pendataan Hak Akses, proses dimulai dengan pengimputan data guru menjadi daftar guru login yang disimpan pada file Guru_Login, kemudian pemberian hak akses kepada guru oleh admin

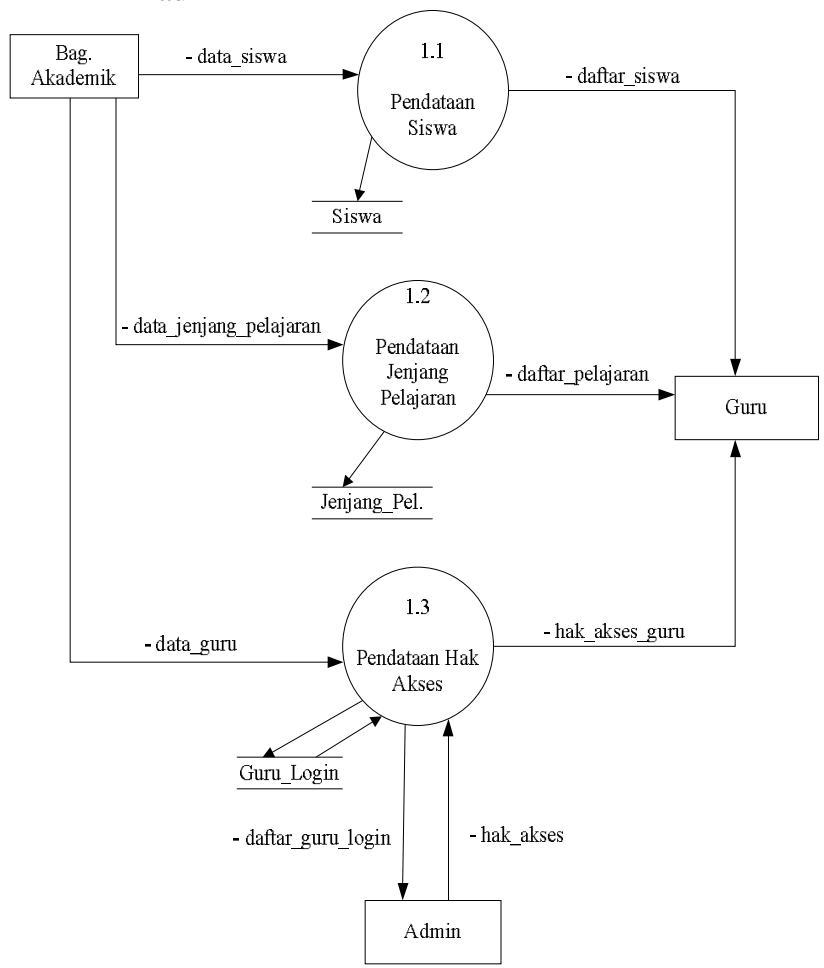

Gambar 4. Diagram Rinci (Level 1) Proses Pendataan

\section{4) Diagram Rinci (Level 1) Proses 2}

Diagram Rinci (Level 1) Proses 2 digunakan untuk menguraikan proses pembelajaran pada diagram Overview, berikut rincian proses pembelajaran dapat dilihat pada Gambar 5. Pada Proses pembelajaran dirinci menjadi 3 subproses, yaitu proses absen siswa, pemberian materi, dan pemberian soal. 


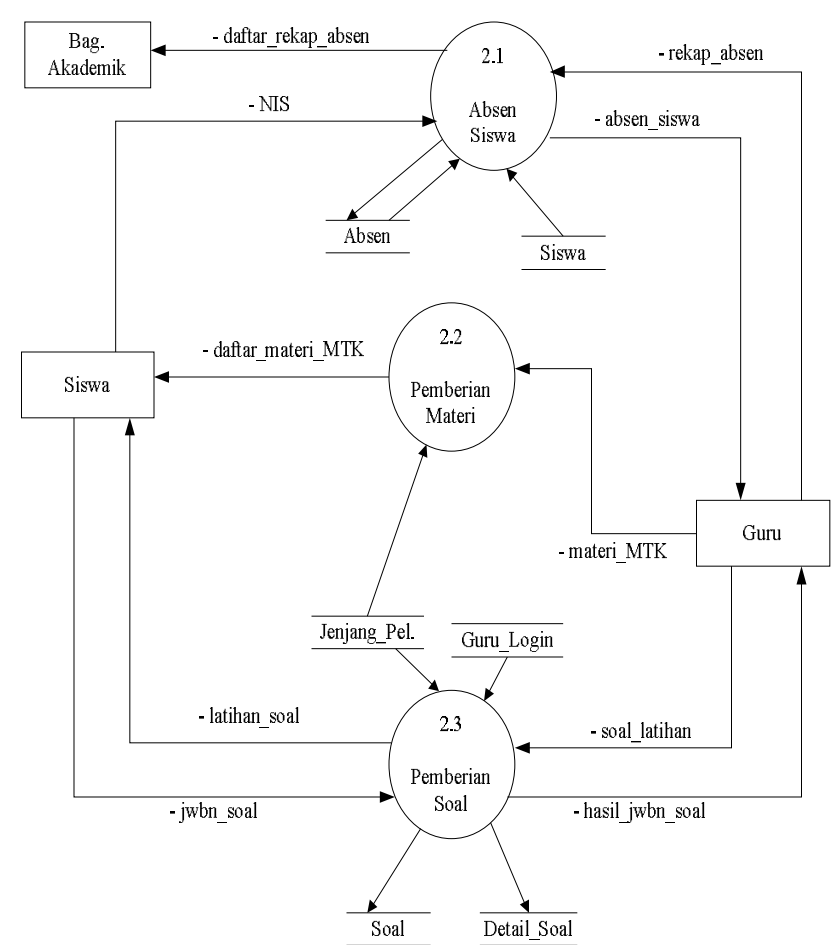

Gambar 5. Diagram Rinci (Level 1) Proses Pembelajaran

Berikut penjelasannya:

a) Proses Absen Siswa, proses ini dimulai dengan pengimputan NIS sebagai absen siswa yang disimpan pada file Absen. Dan membuat rekap absen oleh guru yang diserahkan kepada Bag. Akademik dengan membaca file Absen.

b) Proses Pemberian Materi, pada proses ini guru memberikan materi MTK kepada siswa.

c) Proses Pemberian Soal, proses ini dimulai dengan pengimputan soal latihan menjadi latihan soal yang diberikan kepada siswa dan disimpan pada file Soal dan Detail_Soal. Lalu siswa memberikan jawaban soal tersebut kepada guru.

\section{5) Diagram Rinci (Level 1) Proses 3}

Diagram Rinci (Level 1) Proses 2 digunakan untuk menguraikan proses penilaian pada diagram Overview, berikut rincian proses penilaian dapat dilihat pada Gambar 6. Pada Proses penilaian dirinci menjadi 2 subproses, yaitu proses pembuatan nilai latihan dan pembuatan rekap nilai. Berikut penjelasannya:

a) Proses Pembuatan Nilai Latihan, proses ini dimulai dengan pengimputan nilai siswa dengan membaca file Detail_Soal dan Soal menjadi daftar nilai yang diserahkan kepada siswa. daftar nilai tersebut disimpan pada file Detail_Nilai dan Nilai.

b) Proses Pembuatan Rekap Nilai, Guru membuat rekap nilai menjadi daftar rekap nilai yang akan diserahkan kepada Bag. Akademik.

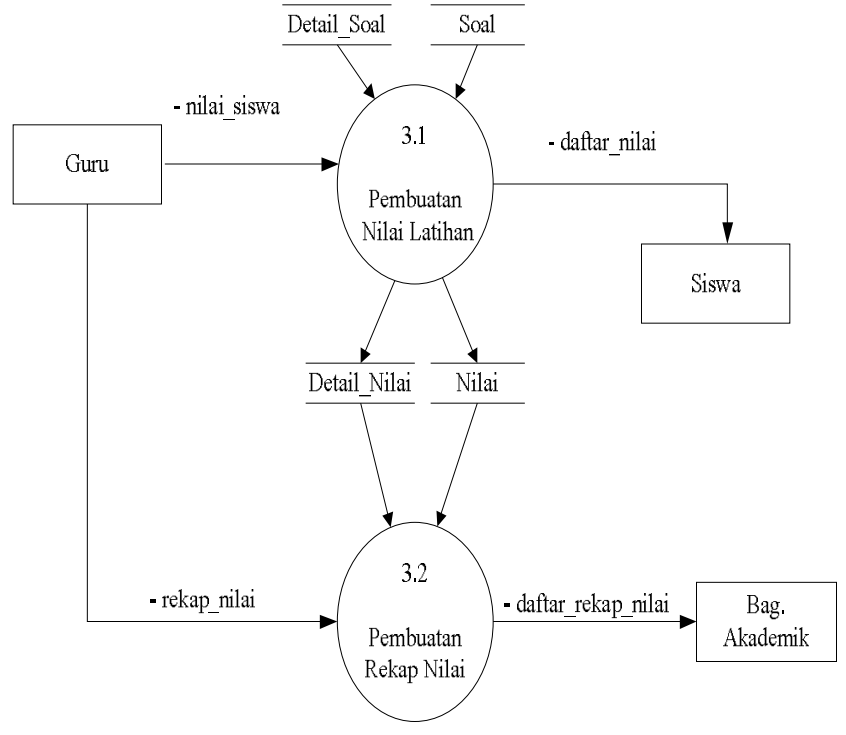

Gambar 6. Diagram Rinci (Level 1) Proses Penilaian

6) Diagram Rinci (Level 2) Proses 1.3

Diagram ini merinci kembali proses pendataan hak akses (proses 1.3). menjadi subproses-subproses yaitu: Pendataan guru login dan pemberian hak akses. Jelasnya dapat dilihat pada Gambar 7.

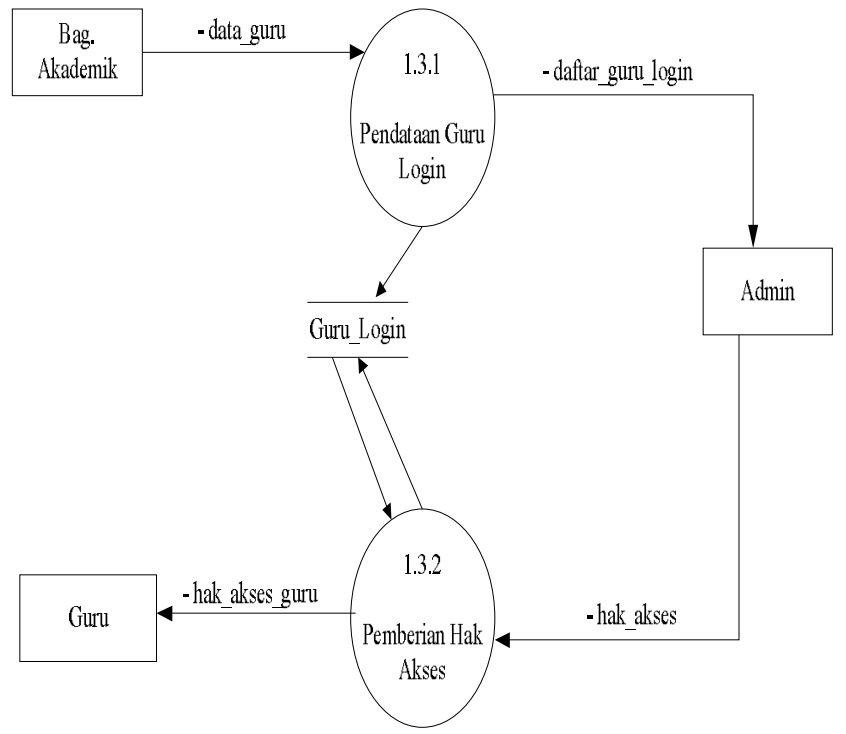

Gambar 7. Diagram Rinci (Level 2) Proses Pendataan Hak Akses

\section{7) Diagram Rinci (Level 2) Proses 2.1}

Diagram ini merinci kembali proses absen siswa (proses 2.1). menjadi subproses-subproses yaitu: Input absen siswa dan rekap absen. Jelasnya dapat dilihat pada Gambar 8. 


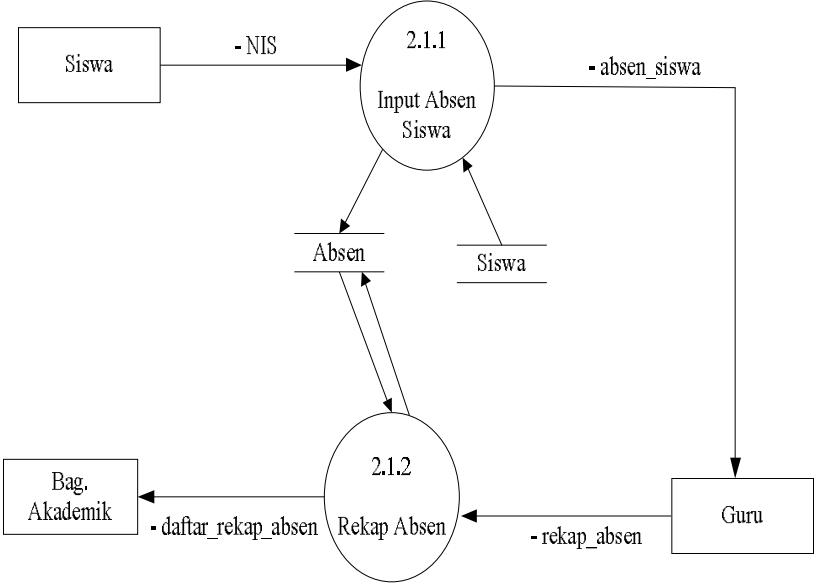

Gambar 8. Diagram Rinci (Level 2) Proses Absen Siswa

\section{8) Diagram Rinci (Level 2) Proses 2.3}

Diagram ini merinci kembali proses pemberian soal (proses 2.3). menjadi subproses-subproses yaitu: Pembuatan soal, dan menjawab soal. Jelasnya dapat dilihat pada Gambar 9.

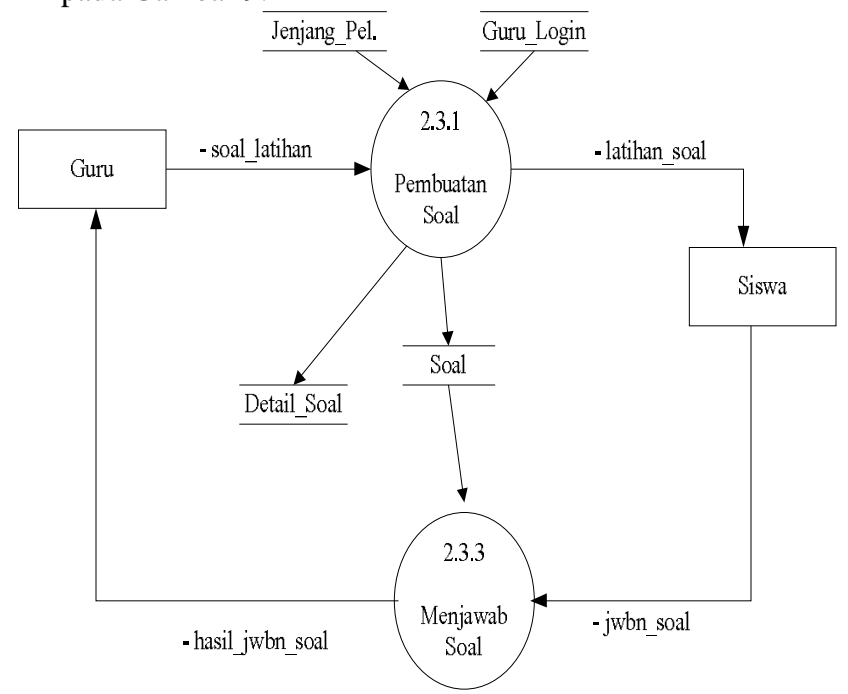

Gambar 9. Diagram Rinci (Level 2) Proses Pemberian Soal

\section{Perancangan STD}

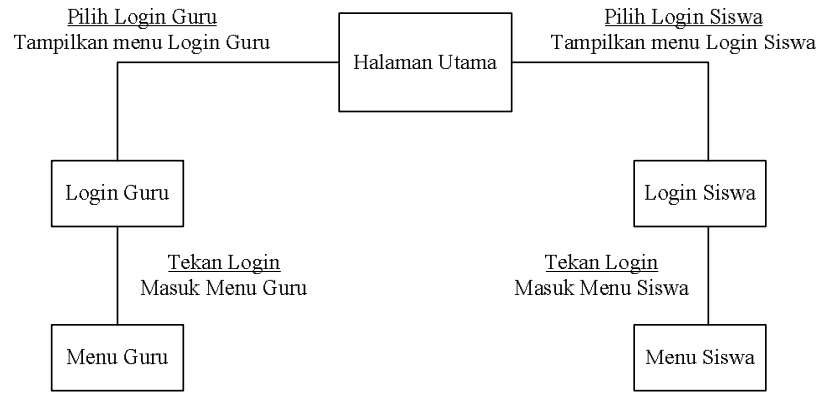

Gambar 10. Rancangan Dialog Halaman Utama

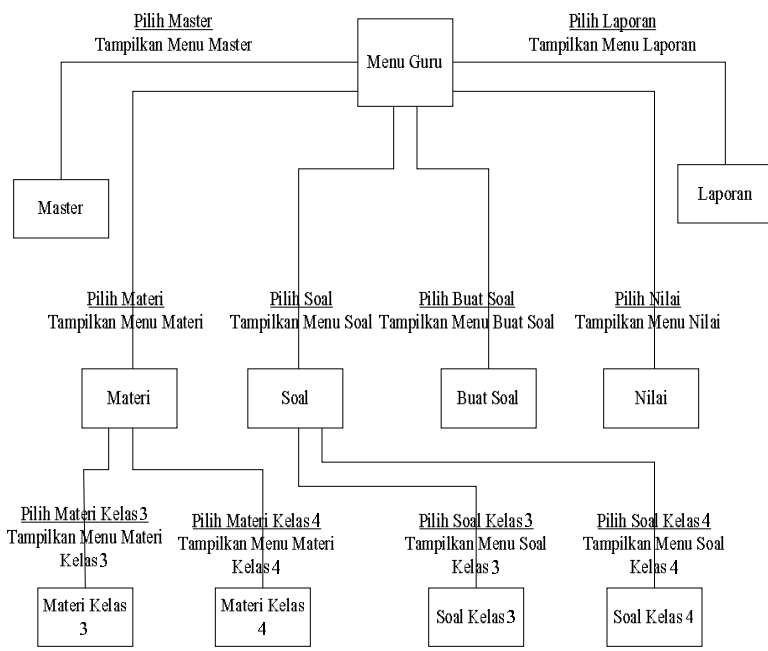

Gambar 11. Rancangan Dialog Menu Guru

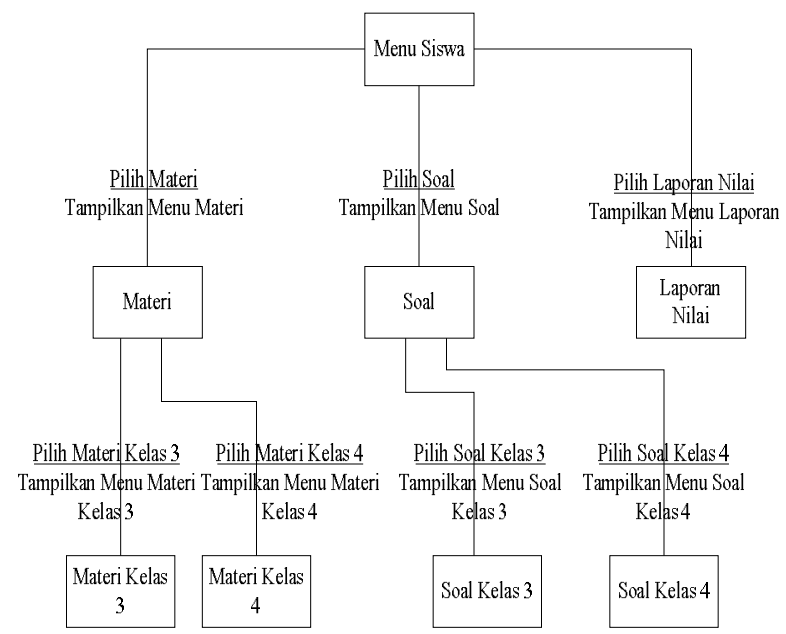

Gambar 12. Rancangan Dialog Menu Siswa

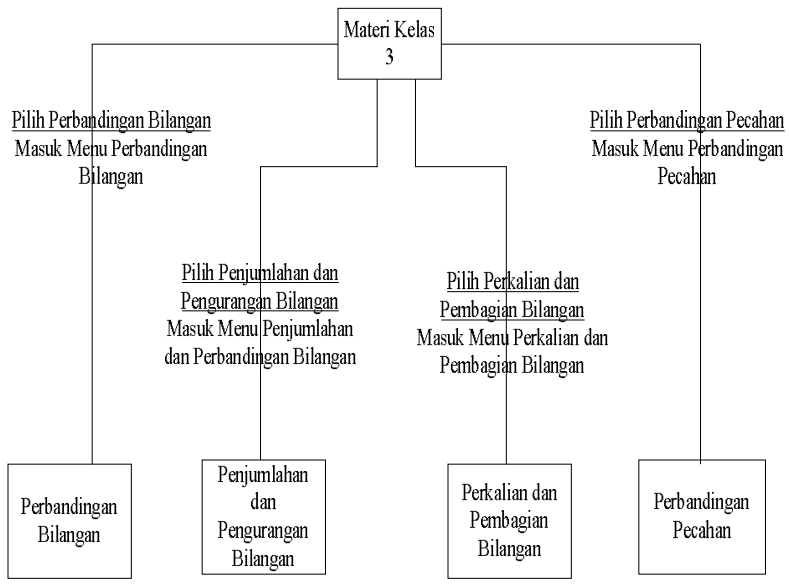

Gambar 13. Rancangan Dialog Menu Materi Kelas 3 


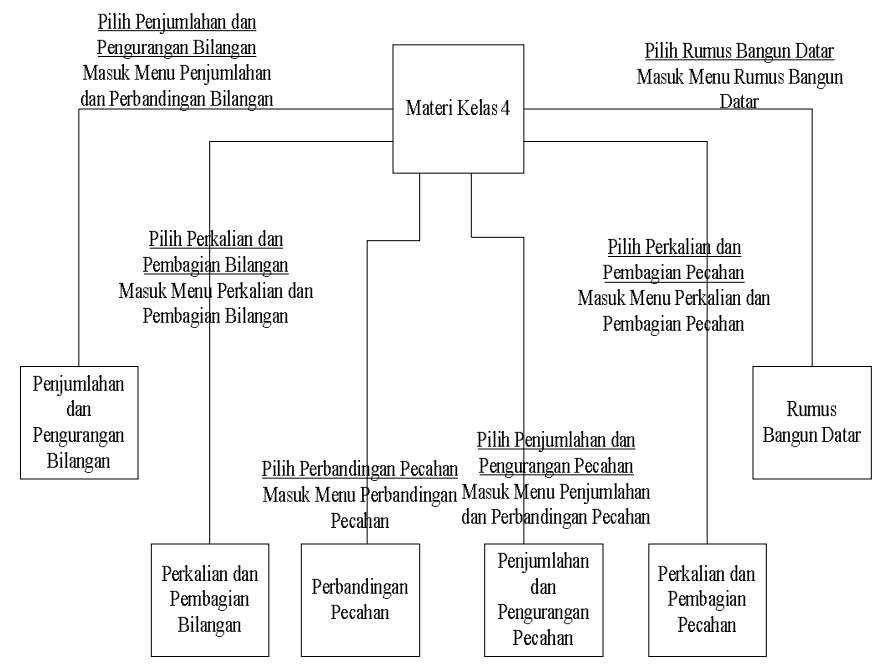

Gambar 14. Rancangan Dialog Menu Materi Kelas 4

\section{PENUTUP}

A. Kesimpulan

Berdasarkan Pengujian dapat disimpulkan :

- Telah diperoleh program pembelajaran matematika dasar kelas 3 dan 4 SD yang terdiri dari 5 pelajaran serta dilengkapi dengan contoh soal, latihan sendiri pada setiap materi, dan latihan soal untuk semua materi sesuai jenjang kelas siswa.

- Guru dapat dengan mudah menginput data siswa, nilai, absen, dan membuat soal latihan.

- Implementasi yang didapat sesuai dengan perancangan STD.

\section{DAFTAR PUSTAKA}

[1] Hartono, Jogiyanto. 1994. Analisis Disain Sistem Informasi Pendekatan Terstruktur Teori dan Praktek Aplikasi Bisnis. Yogyakarta: Andi.

[2] Ismadi, Janu dan Drajat. 2008. Math Stories Kumpulan Rumus dan Cerita Matematika. Bandung: DAR! Mizan.

[3] Karso. 2008. Pendidikan Matematika I. Jakarta: Universitas Terbuka.

[4] Mcleod, Raymond JR, Goerge Schell, Arthur I. Stonehill, \& Michael H. Moffet. 2004. Sistem Informasi Manajemen, Edisi Bahasa Indonesia. Jakarta : Indeks.

[5] Munir. 2010. Kurikulum Berbasis Teknologi, Informasi, dan Komunikasi. Bandung: Alfabeta. 